Note

\title{
Cryopreservation of common carp sperm
}

\author{
Ákos Horváth *, Edit Miskolczi, Béla Urbányi \\ Department of Fish Culture, Szent István University, Páter K.u. 1, 2103 Gödöllö, Hungary
}

Received 29 November 2002; accepted 29 May 2003

\begin{abstract}
Experiments were carried out to investigate the effect of five extenders (sucrose, glucose, fructose, $\mathrm{KCl}$ and a saline carp sperm extender) and two cryoprotectants (dimethyl-sulfoxide (DMSO) and methanol) on the cryopreservation of common carp sperm. Freezing of sperm using glucose extender and methanol as cryoprotectant resulted in the highest post-thaw motility, fertilization as well as hatching rates $(63 \pm 9 \%$, $74 \pm 15 \%$ and $67 \pm 17 \%$ vs. $87 \pm 5 \%, 84 \pm 14 \%$ and $69 \pm 14 \%$ using fresh sperm, respectively). In general, sugar-based extenders combined with methanol as cryoprotectant yielded higher motility, fertilization and hatching rates than ionic extenders in combination with DMSO. The jelly-like agglutination observed after thawing in samples frozen with sugar-based extenders did not reduce fertilization and hatching rates. Frozen-thawed sperm samples were able to successfully fertilize $10 \mathrm{~g}$ (8000) eggs.
\end{abstract}

(C) 2003 Éditions scientifiques et médicales Elsevier SAS and Infremer/IRD/Inra/Cemagref. All rights reserved.

Keywords: Sperm; Cryopreservation; Extenders; Cryoprotectants; Carp

\section{Introduction}

Common carp is the most important cultured fish species in Hungary, consisting 80-85\% of the average annual yield (Horváth and Urbányi, 2000b). However, cryopreservation of its sperm is not used in the hatchery practice in spite of its advantages. The currently existing methods either produce unsatisfactory fertilization and hatching results (Moczarski, 1977; Kurokura et al., 1984; Cognie et al., 1989; Babiak et al., 1997) or they describe the fertilization of minute volumes of eggs: 200-800 eggs altogether (Lubzens et al., 1993; Linhart et al., 2000). They allow the utilization of cryopreservation in frozen gene banks, as it has been reported in Israel (Lubzens et al., 1997) and the Czech Republic (Linhart et al., 2000) but they are impractical for the hatchery practice as it involves the fertilization of large volumes of eggs at the same time.

Moreover, only dimethyl-sulfoxide (DMSO) has been extensively studied as a cryoprotectant for common carp sperm. Therefore, one of our objectives was to investigate the effect of several very simple basic extenders and two cryoprotectants on the motility and fertilizing ability of common carp sperm.

\footnotetext{
* Corresponding author.

E-mail address: ahorvath@kgi.gau.hu (A. Horváth).
}

\section{Materials and methods}

\subsection{Handling of fishes and gamete collection}

Common carp individuals were kept at the Dinnyés Fish Hatchery of the Hungarian Fish Farmers' Association in Dinnyés, Hungary. Four repeats of the experiment were carried out in June 2002. The brood stock (five males and five females for each repeat, 20-20 individuals in total) was collected from the ponds $48 \mathrm{~h}$ before the planned stripping and transported into the hatchery for acclimatization. Males varied between 2 and $4 \mathrm{~kg}$ in weight while females between 3 and $6 \mathrm{~kg}$. Males were injected with $1 \mathrm{U} \mathrm{kg}^{-1}$ of body weight of Ovopel mammalian GnRH analogue (Interfish Ltd., Hungary) $24 \mathrm{~h}$ before the planned stripping (at water temperature of $23{ }^{\circ} \mathrm{C}$ ). This hormone product containing $10-15 \mu \mathrm{g}$ of mammalian GnRH analogue and $2.5-3 \mathrm{mg}$ of water soluble dopamine receptor antagonist metoclopramide was suspended in $0.65 \% \mathrm{NaCl}$ solution and injected into the abdominal cavity of the fishes. Females were injected with the same dose $\left(1 \mathrm{U} \mathrm{kg}^{-1}\right.$ of body weight of this product but in two dosages: the first $-10 \%$ of the total dose - was administered $24 \mathrm{~h}$ before the planned stripping while the remaining $90 \%$ was injected $12 \mathrm{~h}$ later. Before stripping fishes of both sexes, they were anaesthetized in a 5 ppm solution of Quinaldine (Reanal Ltd., Hungary). Anaesthetized fishes were removed from the water, their genital apertures were wiped dry and 
approximately $15 \mathrm{ml}$ of semen was collected from each fish into dry glass tubes while eggs were stripped into dry plastic bowls (0.5-1.5 kg of eggs). Eggs were stored at room temperature until being fertilized 5-30 min following stripping. Sperm was collected approximately $2.5-3 \mathrm{~h}$ before the stripping of eggs and was stored at $4{ }^{\circ} \mathrm{C}$ until being used.

\subsection{Sperm evaluation and cryopreservation}

Sperm of males was diluted in a $200 \mathrm{mM} \mathrm{KCl,} 30 \mathrm{mM}$ Tris (pH 8.0, Saad and Billard, 1987) immobilizing solution in a ratio of 1:99 (10 $\mu \mathrm{l}$ of sperm in $990 \mu \mathrm{l}$ of immobilizing solution). The samples were activated in 1:19 ratio on a microscopic slide by an activating medium (AS; $45 \mathrm{mM}$ $\mathrm{NaCl}, 5 \mathrm{mM} \mathrm{KCl}, 30 \mathrm{mM}$ Tris, $\mathrm{pH} \mathrm{8.0,1} \mu \mathrm{l}$ of diluted sperm in $19 \mu \mathrm{l}$ of activating medium). Motility was observed and the percentage of cells performing progressive forward movement (motility percent) was estimated under light microscope at 200× magnification within the first 15 min following activation.

Following the estimation of motility, three samples showing the highest motility were chosen from the five at each repeat. Sperm samples were diluted at 1:9 ratio in the following extenders: $300 \mathrm{mM}$ sucrose, $30 \mathrm{mM}$ Tris ( $\mathrm{pH} 8.0)$; $350 \mathrm{mM}$ glucose, $30 \mathrm{mM}$ Tris ( $\mathrm{pH} \mathrm{8.0);} 350 \mathrm{mM}$ fructose, $30 \mathrm{mM}$ Tris (pH 8.0), $200 \mathrm{mM} \mathrm{KCl,} 30 \mathrm{mM}$ Tris ( $\mathrm{pH} 8.0)$ and a carp sperm extender composed of $360 \mathrm{mg} \mathrm{NaCl}, 1000 \mathrm{mg}$ $\mathrm{KCl}, 22 \mathrm{mg} \mathrm{CaCl}_{2}, 8 \mathrm{mg} \mathrm{MgCl}_{2}$ and $20 \mathrm{mg} \mathrm{NaHCO}_{3}$ in $100 \mathrm{ml}$ water (modified Kurokura's Extender 2, Magyary et al., 1996). Ten percent DMSO and $10 \%$ methanol were used as cryoprotectants in v/v final concentration (all chemicals were purchased from Reanal Ltd., Hungary). In case of DMSO, equilibration time of 10 min was used while samples with methanol as cryoprotectant were frozen immediately after dilution. The samples were loaded into $0.5 \mathrm{ml}$ straws and frozen in the vapor of liquid nitrogen in a styrofoam box (four straws per sample). Straws were placed horizontally onto styrofoam frames floating on the surface of liquid nitrogen. The height of frames was $3 \mathrm{~cm}$ and the duration of freezing was $3 \mathrm{~min}$. Following freezing, sperm samples were plunged into liquid nitrogen. Straws were kept in liquid nitrogen for about $3 \mathrm{~h}$, except for one case when they were kept in a canister storage Dewar for 1 week. After storage, the samples were thawed in a $40{ }^{\circ} \mathrm{C}$ water bath for $13 \mathrm{~s}$.

\subsection{Fertilization and incubation of eggs}

In each repeat, eggs of three females of the five injected ones were chosen upon visual observation (absence of white eggs, low volume of ovarian fluid). Batches of $10 \mathrm{~g}$ of eggs (approximately 8000 eggs) were fertilized with one straw of frozen sperm $(500 \mu \mathrm{l}$ diluted sperm containing $50 \mu \mathrm{l}$ pure sperm) which corresponds to a sperm to egg ratio of 2.6 to $3.4 \times 10^{4}$. The control was fertilized with $50 \mu \mathrm{l}$ of fresh undiluted sperm. In the process of fertilization, first $2 \mathrm{ml}$ of hatchery water was added to the eggs and then thawed sperm was added immediately. After mixing for approximately
$1 \mathrm{~min}$, the plastic bowl containing the eggs was filled with $150 \mathrm{ml}$ of $0.4 \% \mathrm{NaCl}$ and $0.3 \%$ urea solution to eliminate adhesiveness of eggs. Eggs were kept in this solution for about $1 \mathrm{~h}$, then they were washed twice in 5\% tannic acid for $20 \mathrm{~s}$ and incubated, in standard hatchery conditions in 71 Zuger-jars, with the final flow rate of $1-1.51 / \mathrm{min}$. All treatments were conducted at the temperature of $23{ }^{\circ} \mathrm{C}$. Fertilization was assessed first at 4-8-cell stage $1.5 \mathrm{~h}$ after fertilization by counting approximately 150 eggs, then after hatching. The number of repeats of fertilization results is higher than the hatching rates because on the first week, eggs were not incubated following fertilization and the sperm frozen on the first week was reused for fertilization in the second repeat.

\subsection{Statistical analysis of the data}

Statistical analysis of the data was carried out using GraphPad Instat version 3.01 statistical software (GraphPad Software, Inc., San Diego, California, USA). Motility, fertilization and hatching results were subjected to one-way analysis of variance (ANOVA) at the significance level of $P \leq 0.05$ followed by a Turkey Kramer Multiple Comparisons test. Normal distribution of the data was verified prior to the analyses.

\section{Results}

The average motility of fresh common carp sperm was $87 \pm 5 \%(n=9)$. The highest post-thaw motility $(63 \pm 9 \%$, $n=9$ ) was achieved using the glucose extender and methanol as cryoprotectant (Fig. 1a), which did not differ from the control. A jelly-like agglutination of sperm was observed after thawing in samples frozen with sugar-based extenders regardless of the cryoprotectant. When observed under the microscope, individual spermatozoa were released from the jelly-like substance. Agglutinated sperm did not mix with the eggs homogeneously. The highest fertilization rate at 4-cell stage (Fig. 1b) was achieved with sperm frozen with the glucose and fructose extenders and methanol as cryoprotectant in both cases $(74 \pm 15 \%$ and $71 \pm 12 \%$, respectively, $n=12$ ). No statistically significant difference was detected between these treatments and the control $(84 \pm 12 \%, n=12)$. However, all samples frozen with methanol as cryoprotectant resulted in a high percentage of fertilized eggs and with the exception of the $\mathrm{KCl}$ extender, they were all significantly different from their equivalents frozen with DMSO $(P<0.001$ in case of all extenders $)$. The highest hatching rate (Fig. 1c) was also achieved with the use of glucose and fructose extenders and methanol. There was no difference in the hatching rates between the samples frozen with glucose and fructose extenders and methanol as cryoprotectant and the control group $(67 \pm 17 \%, 55 \pm 18 \%$ and $69 \pm 14 \%$, respectively, $n=9$ ). The hatching rates of eggs fertilized with sperm frozen with sucrose, fructose and glucose extenders combination with methanol were different from their equiva- 
a.

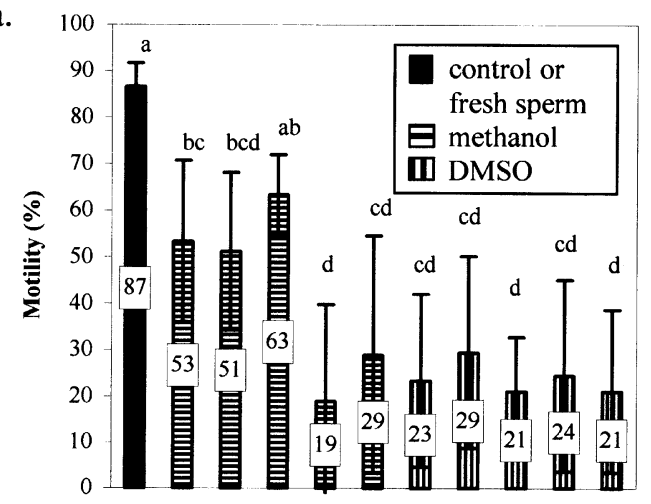

b.

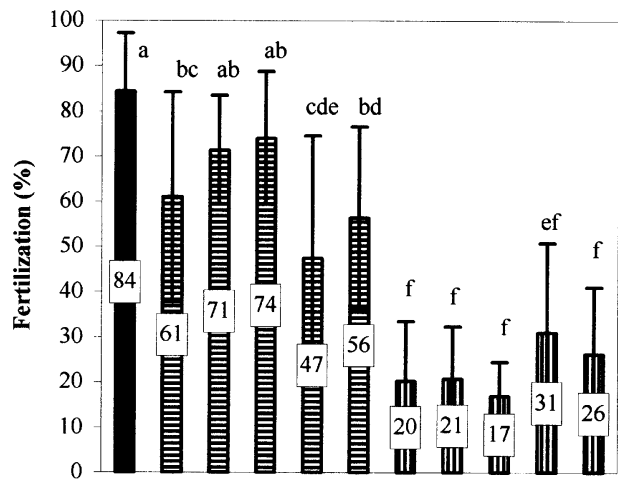

c.

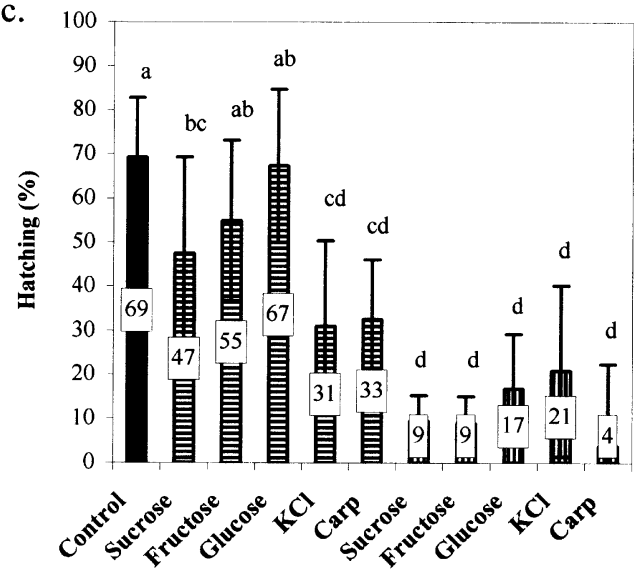

Fig. 1. Post-thaw motility (a) fertilization (b) and hatching (c) results achieved with cryopreserved common carp sperm. Columns marked with the same letter within the same chart are not significantly different at $P \leq 0.05$ (motility: $n=9$; fertilization: $n=12$; hatching: $n=9$ ).

lents frozen in presence of DMSO $(P<0.001$ for all listed extenders).

\section{Discussion}

According to our results, the utilization of sugar-based extenders-glucose and fructose-produced significantly higher fertilization and hatching results than ionic extenders. Simple sugar-based extenders have been tested on common carp sperm (Babiak et al., 1997) with little success. Fructose and glucose were reported as components of different extenders for the freezing of sperm of other cyprinid species (Kumar, 1988; Zhang and Liu, 1991). Most publications report the use of either Kurokura's Original Extender 1 and 2 (Kurokura et al., 1984, Lubzens et al., 1993), its modifications (Magyary et al., 1996) or other ionic solutions (Lahnsteiner et al., 2000). Sugar extenders were successfully used for the cryopreservation of sperm of several other fish species such as African catfish (Clarias gariepinus) (Steyn and Van Vuren, 1987; Urbányi et al., 1999) and various sturgeon species (Tsvetkova et al., 1996; Glogowski et al., 2002). The success of sugars as extenders can be explained by their role as external cryoprotectants and membrane stabilizers (Maisse, 1996). In our case, the use of sugar-based extenders resulted in a jelly-like agglutination of spermatozoa. Nevertheless, these samples were able to fertilize the eggs and resulted in a higher fertilization and hatching rate than the ones frozen with ionic extenders. This type of agglutination is a known phenomenon (F. Lahnsteiner, University of Salzburg, Austria, personal communication). Although agglutinated sperm did not mix homogeneously with eggs, it seems that a sufficient number of individual spermatozoa were released from it to ensure fertilization. Based on these results, sperm samples showing this type of agglutination should not be discarded, they are safe to use for fertilization.

We found that methanol was a far more efficient cryoprotectant for common carp sperm than DMSO. To the best of our knowledge, this is the first report on the utilization of methanol as a successful cryoprotectant in this species. Lubzens et al. (1993) used it in combination with Kurokura's Extender 1 without success. Methanol has been successfully used for the cryopreservation of other cyprinid species such as the zebrafish (Danio rerio) (Harvey et al., 1982) as well as fish species of other taxa such as salmonids (Lahnsteiner et al., 1997), catfishes (Steyn, 1993; Steyn and Van Vuren, 1987; Tiersch et al., 1994) or tilapias (Harvey, 1983). All other studies on common carp reported the efficient use of DMSO except for Babiak et al. (1997) who achieved his best results with dimethyl-acetamide (DMA). Methanol is found surprisingly nontoxic when used as a cryoprotectant and has been found superior to DMSO or glycerol in a number of cell types (Harvey et al., 1982) including sturgeon spermatozoa (Horvath and Urbányi, 2000a). It is known for its extreme rapidity to penetrate cells (Ashwood-Smith, 1980), however, the particulars of its action as a cryoprotectant remain unclear.

\section{Conclusion}

Our results indicate that methanol as a cryoprotectant is a reasonable alternative to DMSO for the cryopreservation of common carp sperm. It also seems that simple sugar-based extenders are just as reliable for cryopreservation as saline ones. In case of sugar-based extenders, a jelly-like agglutination of the sperm and the cryodiluent was observed during 
thawing; however this phenomenon did not affect the fertilizing capacity of the sperm. This agglutination was not as strong in case of the glucose extender as in others. We were able to successfully fertilize $10 \mathrm{~g}$ (8000) of eggs with one $0.5 \mathrm{ml}$ straw of frozen-thawed carp sperm.

\section{Acknowledgements}

The authors would like to express their gratitude to $\mathrm{R}$. Szabó, Gy. Megyeri and B. Németh of the Dinnyés Fish Hatchery for their help in the hatchery work. The work was supported by the FKFP 0033/2001, OTKA D 38498 and OTKA F 038389 grants.

\section{References}

Ashwood-Smith, M.J., 1980. Low-temperature preservation of cells, tissues and organs. In: Ashwood-Smith, M.J., Farrant, J. (Eds.), Lowtemperature Preservation in Medicine and Biology. Pitman Medical, Turnbridge Wells, pp. 19-45.

Babiak, I., Glogowski, J., Brzuska, E., Szumiec, J., Adamek, J., 1997. Cryopreservation of sperm of common carp, Cyprinus carpio L. Aquac. Res. 28, 567-571.

Cognie, F., Billard, R., Chao, N.H., 1989. La cryoconservation de la laitance de la carpe, Cyprinus carpio. J. Appl. Ichthyol. 5, 165-176.

Glogowski, J., Kolman, R., Szczepkowski, M., Horvath, A., Urbányi, B., Sieczyński, P., Rzemieniecki, A., Domagała, J., Demianowicz, W., Kowalski, R., Ciereszko, A., 2002. Fertilization rate of Siberian sturgeon (Acipenser baeri, Brandt) milt cryopreserved with methanol. Aquaculture 211, 367-373.

Harvey, B., 1983. Cryopreservation of Sarotherodon mossambicus spermatozoa. Aquaculture 32, 313-320.

Harvey, B., Kelley, R.N., Ashwood-Smith, M.J., 1982. Cryopreservation of zebra fish spermatozoa using methanol. Can. J. Zool. 60, 1867-1870.

Horváth, Á., Urbányi, B., 2000a. Cryopreservation of sterlet (Acipenser ruthenus) sperm. In: Norberg, B., Kjesbu, O.S., Taranger, G.L., Andersson, E., Stefansson, S.O. (Eds.), Reproductive Physiology of Fish. University of Bergen, Bergen, Norway, pp. 441 p.

Horváth, L., Urbányi, B., 2000b. Fish species bred in Hungary. In: Horváth, L. (Ed.), Fish Biology and Fish Breeding. Mezőgazda Kiadó, Budapest, pp. 229-343 (in Hungarian).

Kumar, K., 1988. A comparative study of various extenders for cryopreservation of carp spermatozoa. Ind. J. Anim. Sci. 58, 1355-1360.
Kurokura, H., Hirano, R., Tomita, M., Iwahashi, M., 1984. Cryopreservation of carp sperm. Aquaculture 37, 267-273.

Lahnsteiner, F., Weismann, T., Patzner, R.A., 1997. Methanol as cryoprotectant and the suitability of $1.2 \mathrm{ml}$ and $5 \mathrm{ml}$ straws for cryopreservation of semen from salmonid fishes. Aquac. Res. 28, 471-479.

Lahnsteiner, F., Berger, B., Horvath, A., Urbányi, B., Weismann, T., 2000. Cryopreservation of spermatozoa in cyprinid fishes. Theriogenology 54, 1477-1498.

Linhart, O., Rodina, M., Cosson, J., 2000. Cryopreservation of sperm in common carp Cyprinus carpio: sperm motility and hatching success of embryos. Cryobiology 41, 241-250.

Lubzens, E., Rothbard, S., Hadani, A., 1993. Cryopreservation and viability of spermatozoa from the ornamental Japanese carp (nishikigoi). Bamidgeh 45, 169-174.

Lubzens, E., Daube, N., Pekarsky, I., Magnus, Y., Cohen, A., Yusefovich, F., Feigin, P., 1997. Carp (Cyprinus carpio L.) spermatozoa cryobanks. Strategies in research and application. Aquaculture 155, 13-30.

Magyary, I., Urbányi, B., Horváth, L., 1996. Cryopreservation of common carp (Cyprinus carpio L.) sperm II. Optimal conditions for fertilization. J. Appl. Ichthyol. 12, 117-119.

Maisse, G., 1996. Cryopreservation of fish semen: a review. Proceedings of the Refrigeration Science and Technology Conference, Refrigeration and Aquaculture. Institut International du Froid, Paris, France, pp. 443-467.

Moczarski, M., 1977. Deep freezing of carp (Cyprinus carpio L.) sperm. Bull. Acad. Pol. Sci. Ser. Sci. Biol. 24, 187-190.

Saad, A., Billard, R., 1987. Spermatozoa production and volume of semen collected after hormonal stimulation in the carp, Cyprinus carpio. Aquaculture 65, 67-77.

Steyn, G.J., 1993. The effect of freezing rate on the survival of cryopreserved African sharptooth catfish (Clarias gariepinus) spermatozoa. Cryobiology $30,581-590$.

Steyn, G.J., Van Vuren, J.H.J., 1987. The fertilizing capacity of cryopreserved sharptooth catfish (Clarias gariepinus) sperm. Aquaculture 63, 187-193.

Tiersch, T.R., Goudie, C.A., Carmichael, G.J., 1994. Cryopreservation of channel catfish sperm: storage in cryoprotectants, fertilization trials and growth of channel catfish produced with cryopreserved sperm. Trans. Am. Fish Soc. 123, 580-586.

Tsvetkova, L.I., Cosson, J., Linhart, O., Billard, R., 1996. Motility and fertilizing capacity of fresh and frozen-thawed spermatozoa in sturgeons Acipenser baeri and A. ruthenus. J. Appl. Ichthyol. 12, 107-112.

Urbányi, B., Horváth, Á., Varga, Z., Horváth, L., Magyary, I., Radics, F., 1999. Effect of extenders on sperm cryopreservation of African catfish, Clarias gariepinus (Burchell, 1822). Aquac. Res. 30, 145-151.

Zhang, X., Liu, Y., 1991. Study on the cryopreservation of fish spermatozoa. Acta Sci. Nat. Univ. Norm. Hunan. 14, 255-259 (in Chinese with English abstract). 